\title{
DNA Fingerprinting and Cloning of Hypervariable Minisatellite Repeats in Salmonids
}

\author{
F.C. Leung', M. Welt, R.D. Quesenberry, and X-Z. Shen \\ Pacific Northwest Laboratory, Department of Biology and Chemistry, MS K4-13, P.O. Box 999, Richland, WA 99352, USA
}

Leung, F.C., M. Welt, R.D. Quesenberry, and X-Z. Shen. 1994. DNA fingerprinting and cloning of hypervariable minisatellite repeats in salmonids. Can. J. Fish. Aquat. Sci. 51(Suppl. 1): 258-266.

\begin{abstract}
We used heterologous Jeffreys' 33.6 core sequence and microsatellites $(C A C)_{5}$ and $(C A)_{12}$ as probes and compared them with probes based on the minisatellite sequences from tilapia (Oreochromis niloticus) and Atlantic salmon (Salmo salar) in fingerprinting assays. DNA fingerprints generated with the Jeffreys' 33.6 core sequence and the microsatellite $(C A C)_{5}$ and $(C A)_{12}$ probes showed complex profiles with high background, but DNA fingerprints using the tilapia and Atlantic salmon probes showed clear, less complex, informative, individual-specific DNA fingerprints suitable for analysis. We cloned and sequenced homologous repetitive sequences using a novel approach of creating a chinook salmon (Oncorhynchus tshawytscha) genomic DNA library with enriched low $C_{0} t$ DNA repeats for the development of DNA probes. The four types of repeats identified and sequenced were $(C T)_{n}$ and three Alu-like sequences. We generated DNA fingerprints using one of the minisatellite sequences as a probe. This minisatellite sequence was shown to be species specific because it is abundant in chinook and coho salmon (Oncorhynchus kisutch) genomes, but not in Atlantic salmon. These probes will provide us with the tools to study pedigree and linkage analysis, paternity testing, breeding programs, and the analysis of genetic structure within populations for aquaculture and fisheries research.
\end{abstract}

Nous avons utilisé la séquence noyau hétérologue 33,6 de Jeffrey et les microsatellites $(C A C)_{5}$ et $(C A)_{12}$, servant de sondes et les ont comparées, dans des analyses de cartographie d'ADN, à des sondes en séquences minisatellites obtenues du tilapia (Oreochromis niloticus) et du saumon de l'Atlantique (Salmo salar). Les empreintes digitales d'ADN obtenues à l'aide de la séquence noyau 33,6 de Jeffrey et des sondes microsatellites $(C A C)_{5}$ et $(C A)_{12}$ montrent des profils complexes, mais les empreintes d'ADN obtenues à l'aide des sondes du tilapia et du saumon de l'Atlantique étaient claires, moins complexes, informatives et caractéristiques de l'individu, se prétant ainsi à l'analyse. Les auteurs ont cloné des séquences homologues répétitives et en ont établi les séquences selon une nouvelle approche, soit en créant une bibliothèque d'ADN génomique du saumon quinnat (Oncorhynchus tshawytscha) à l'aide de répétitions enrichies d'ADN pour la mise au point de sondes en ADN faible en $\mathrm{C}_{0}$ t. Ils ont identifié et établi la séquences de quatre types de répétitions, soit $(\mathrm{CT})_{n}$ et trois séquences de type Alu. lls ont en outre obtenu des empreintes d'ADN en se servant d'une des séquences minisatellites comme sonde, et ont démontré que cette séquence était caractéristique de l'espèce parce qu'elle était abondante dans les génomes des saumons quinnat et coho, (Oncorhynchus kisutch), mais non du saumon de l'Atlantique. Ces sondes pourront servir d'outils aux analyses de généalogie et de parenté, aux recherches de paternité, à l'évaluation des programmes de sélection de géniteurs et à l'analyse de la structure génétique de populations à des fins d'élevage et de recherche halieutique.

Received June 8, 1993

Accepted September 12, 1994

(JB2443)

sozyme protein electrophoresis markers have traditionally been used by fisheries scientists to study genetic variation between hatchery and wild fish populations (Aebersold et al. 1987; Davis et al. 1990). Recently, restriction fragment length polymorphism and sequence polymorphism of mitochondrial DNA (mtDNA) have provided additional genetic markers for measuring genetic relatedness. However, mtDNA analyses do not always provide individual genetic identification, and the ability to detect population diversity using only mtDNA can be limited (Waldman et al. 1988; Smith et al. 1989; Shields et al. 1992). The advent of DNA fingerprinting hăs allowed scientists in fisheries and aquaculture research to develop genetic markers that

\footnotetext{
${ }^{1}$ Current address: Department of Zoology, University of Hong Kong, Pokfulam Road, Hong Kong.
}

are more polymorphic than those revealed by conventional isozyme electrophoresis and mtDNA analyses (Wright 1993).

The lack of suitable specific probes for fish genetic analysis has slowed the introduction of DNA fingerprinting into fisheries applications. Using heterologous probes from human $A l u$, M13, and others, DNA fingerprints have been generated for a variety of fish (Wright 1993). Jeffreys' probes 33.6 and 33.15 have been used to fingerprint tilapia (Oreochromis niloticus) (Harris et al. 1991; Bentzen et al. 1991), rainbow trout (Oncorhynchus mykiss), and Atlantic salmon (Salmo salar) (Bentzen et al. 1991). Fields et al. (1989) used M13 as a probe and successfully fingerprinted rainbow trout, chum salmon (Oncorhynchus keta), coho salmon (Oncorhynchus kisutch), and Atlantic salmon. Using the M13 probe, Rico et al. (1991) fingerprinted the threespine stickleback (Gasterosteus aculeatus) and Wirgin et al. (1991) fingerprinted 


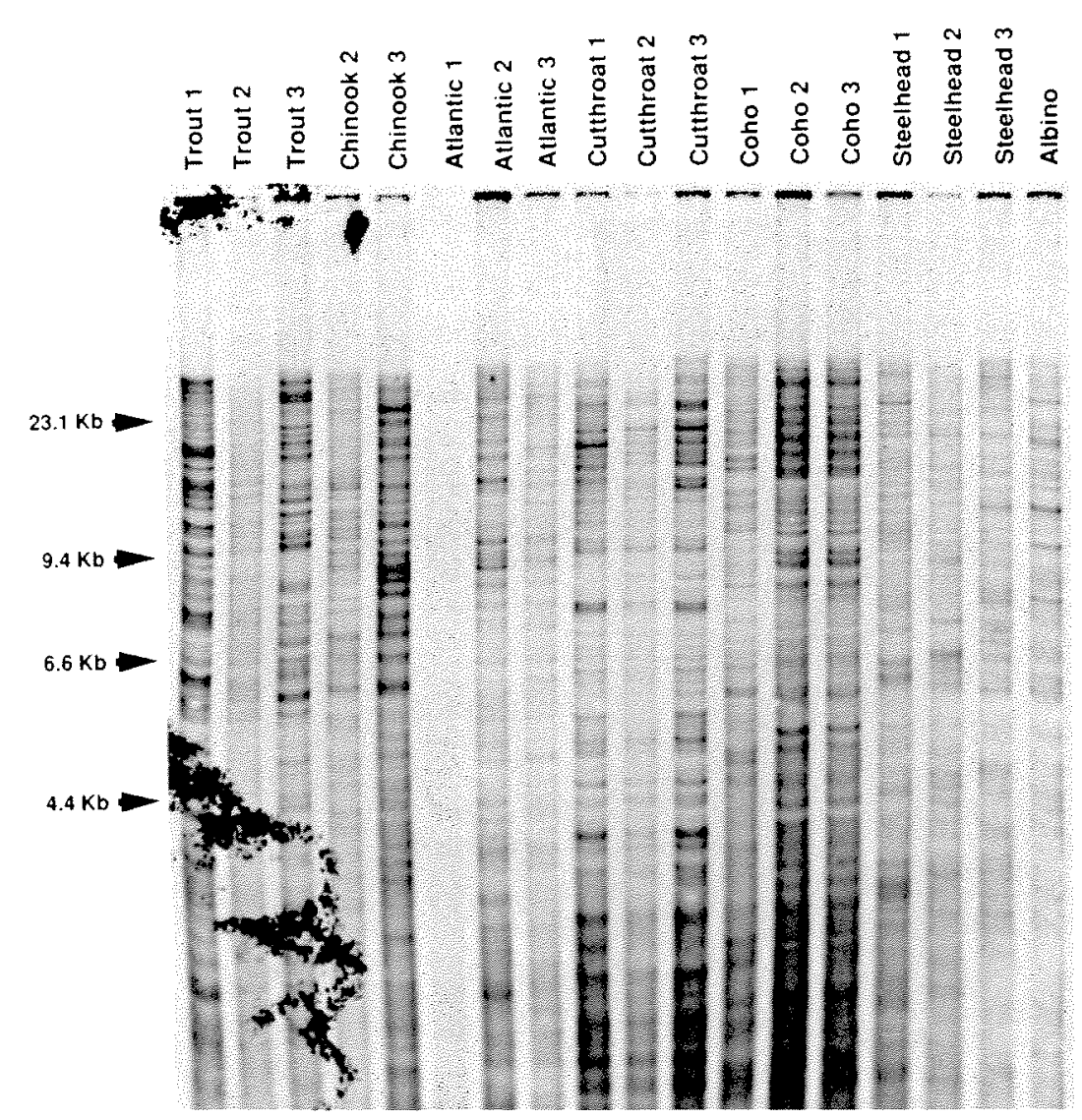

FIG. 1. DNA fingerprints of five species of salmonids. DNA from five species of salmonids was digested with Alu I and probed with 33.6 core. Trout $=$ rainbow trout, Chinook $=$ chinook salmon, Atlantic $=$ Atlantic salmon, Cutthroat $=$ Yellowstone cutthroat trout, Coho $=$ Coho salmon, Steelhead $=$ steelhead.

the striped bass (Morone saxatilis). Lloyd et al. (1989) used BKm minisatellites as a probe and revealed DNA polymorphism in the rainbow trout. Additional microsatellite probes such as $(\mathrm{CAC})_{5},(\mathrm{GACA})_{4},(\mathrm{CA})_{8}$, and others (Epplen et al. 1991) have been used in other fish species, including Poecilia sp. and Xiphophorus sp. However, the cross hybridization of these heterologous probes has usually generated fingerprints that contain numerous crowded bands of varying intensity, making interpretation and analysis difficult.

Repetitive sequences including satellites, minisatellites, microsatellites, short interspersed elements (SINE), and long interspersed elements (LINE) are found in all eukaryotic genomes (Brutlag 1980; Singer 1982; Miklos 1985). They have been extensively studied in mammals (Singer 1982; Arnason and Widegren 1984; Miklos 1985, Chen et al. 1989) and recently in fish (Datta et al. 1988; Moyer et al. 1988; Wright 1989; Denovan and Wright 1990; Bentzen and Wright 1993). These repetitive sequences have attracted considerable interest as genetic markers for chromosome mapping and phylogenetic studies (Rohrer et al. 1994; Fanning et al. 1989). Using a homologous minisatellite variable number of tandem repeats (VNTR), Bentzen and Wright (1993) generated clear and highly polymorphic DNA fingerprints in salmonid fish.

In this paper, we reported the DNA fingerprinting of salmonids using five probes: Jeffreys' 33.6 core sequence, microsatellite $(\mathrm{CAC})_{5}$ and $(\mathrm{CA})_{12}$, a tilapia minisatellite and an Atlantic salmon minisatellite. In addition, we report on the cloning of hypervariable minisatellite repeats in chinook salmon and on the use of these repeats as a probe in DNA fingerprinting.

\section{Materials and Methods}

\section{DNA Isolation}

Blood samples were obtained from the University of Washington and from the National Marine Fisheries Service (both in Seattle, Washington). DNA was extracted from five species of salmonids including coho salmon, chinook salmon, Atlantic salmon, Yellowstone cutthroat trout, steelhead and rainbow trout. Rainbow trout samples, including albino trout, were also collected from the Pacific Northwest Laboratory hatchery (Richland, Washington).

The blood samples were stored in EDTA anticoagulant vacutainers at $4^{\circ} \mathrm{C}$ for $48 \mathrm{~h}$ and then in $350-\mu \mathrm{L}$ aliquots at $-80^{\circ} \mathrm{C}$. DNA was isolated according to a modified Federal Bureau of Investigation protocol (Kirby 1992). Blood samples were thawed at $37^{\circ} \mathrm{C}$ and resuspended in $800 \mu \mathrm{L}$ of $1 \times \mathrm{SSC}$ $(1 \times \mathrm{SSC}=0.15 \mathrm{M} \mathrm{NaCl}, 0.015 \mathrm{M}$ sodium citrate, $\mathrm{pH} 7.0)$ with gentle vortexing. Cells were pelleted at $8000 \times g$, the supernatant removed and the pellet resuspended in $1 \mathrm{~mL}$ $1 \times \mathrm{SSC}$, as before. Cells were pelleted again and resuspended in $375 \mu \mathrm{L}$ of $0.3 \mathrm{M}$ sodium acetate ( $\mathrm{pH}$ 5.2). Sodium dodecyl sulfate (SDS), $0.5 \%$, and $300 \mu \mathrm{g}$ proteinase $\mathrm{K}$ (Sigma) were added to the suspension and mixed by inversion. Cells were incubated at $55^{\circ} \mathrm{C}$ with periodic agitation until the pellet was fully dissolved, usually for $1.5-2.0 \mathrm{~h}$. 


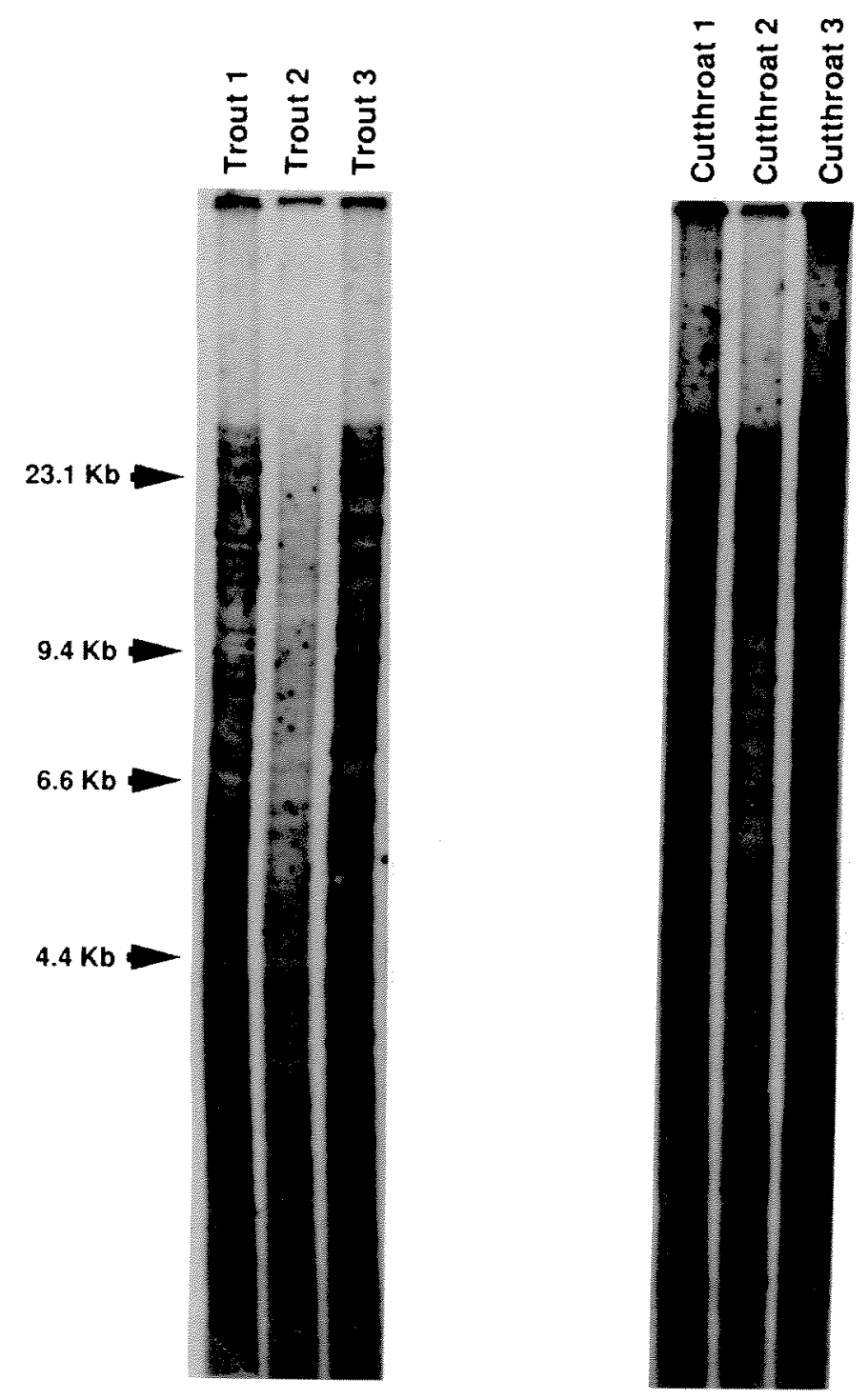

FIG. 2. DNA fingerprints from three rainbow trout and three Yellowstone cutthroat trout. DNA was digested with $A l u I$ and probed with $(\mathrm{CAC})_{5}$.

When digestion was complete, $480 \mu \mathrm{L}$ of $10 \mathrm{mM}$ Tris, InM EDTA (TE) ( $\mathrm{pH} 7.8$ ) buffered phenol was added and mixed by inversion for at least $30 \mathrm{~s}$, and the phases were separated with a 2 -min spin at $16000 \times g$ in a microcentrifuge. The bottom organic layer was removed with a glass pipette, and the remaining aqueous layer extracted two more times with an equal volume of water-saturated phenol chloroform - isoamyl alcohol (25:24:1), followed by two extractions with an equal volume of chloroform - isoamyl alcohol (24:1). The remaining aqueous layer was transferred to a new tube and nucleic acids precipitated by adding $1 \mathrm{~mL}$ of ice-cold absolute ethanol and incubating at room temperature for $10 \mathrm{~min}$. DNA was recovered by centrifugation at $16000 \times \mathrm{g}$, and the pellet was redissolved in $180 \mu \mathrm{L}$ of TE. Nucleic acids were then reprecipitated with $1 / 10$ volume of sodium acetate ( $3 \mathrm{M}, * \mathrm{pH} 5.2)$ and ethanol and the resulting pellet was washed with $70 \%$ ethanol and dried under vacuum for $5 \mathrm{~min}$. The final DNA pellet was redissolved in TE and quantified by Hoescht 33582 staining with a Hoefer TKO minifluorometer.
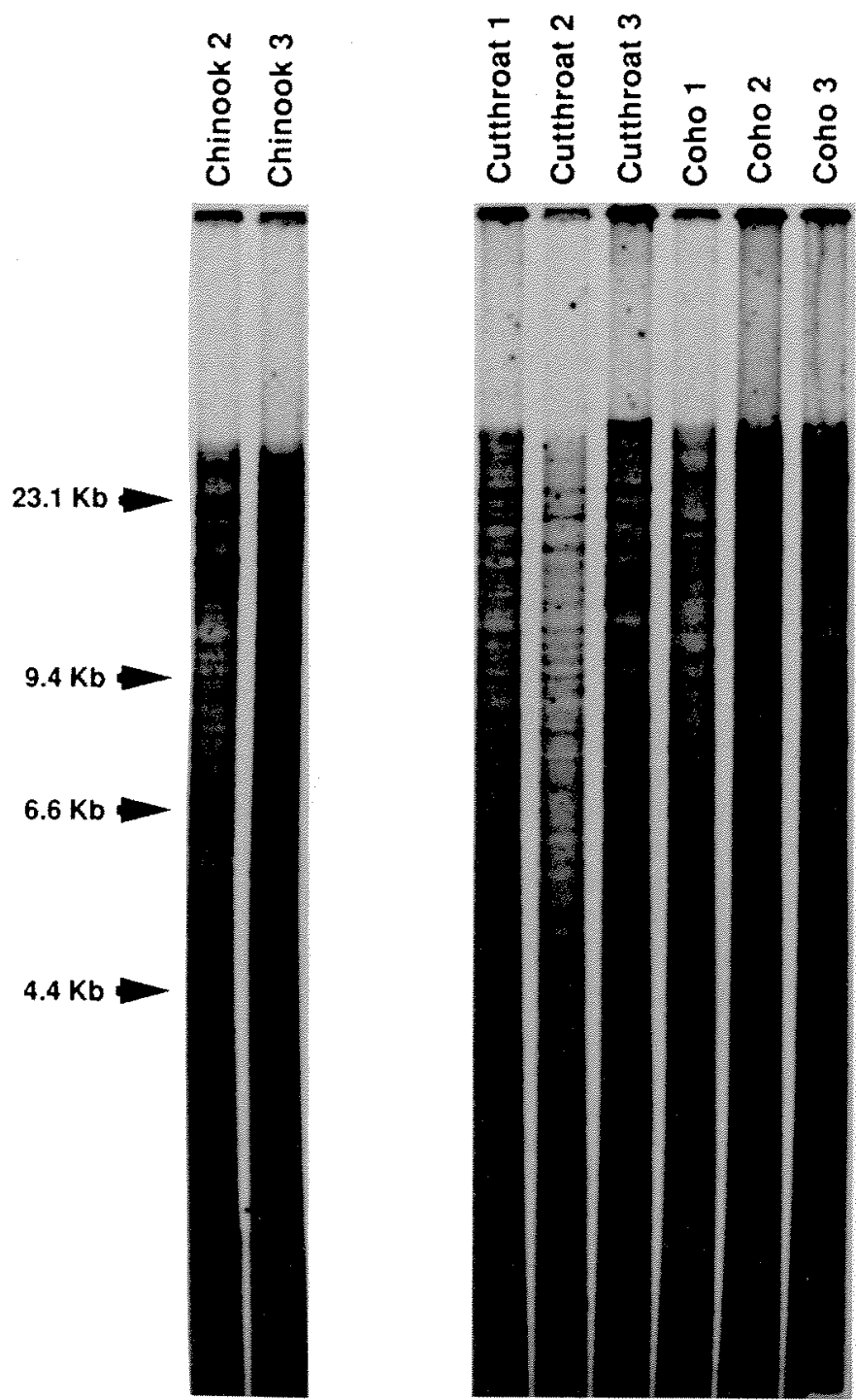

FIG. 3. DNA fingerprints from three Yellowstone cutthroat trout, two chinook, and three coho salmon. DNA was digested with AluI and probed with $(\mathrm{CA})_{12}$.

\section{Enzyme Digestion and Electrophoresis}

Ten micrograms of genomic DNA were digested overnight with 50 units $A l u \mathrm{I}$, HaeIII or HinfI (GIBCO/BRL, Gaithersburg, MD) in $100-\mu \mathrm{L}$ total volume. Digested DNA was precipitated with ammonium acetate, washed with $70 \%$ ethanol, dried under vacuum, and resuspended in $20-\mu \mathrm{L}$ of TE. DNA was separated in $0.7 \%$ agarose gels (Seakem GTG, FMC) in $40 \mathrm{mM}$ Tris-acetate, 1mM EDTA (TAE) (pH 8.0) buffer at $1.5 \mathrm{~V} / \mathrm{cm}, 6^{\circ} \mathrm{C}$ for $48 \mathrm{~h}$ and was transferred to Magnagraph nylon membranes (MSI Inc.) using a Pharmacia VacuGene XL blotting system and the acid depurination protocol supplied by the manufacturer. Nucleic acids were fixed to the nylon membrane by UV crosslinking in a Stratagene model $1800 \mathrm{UV}$ Stratalinker at $1200 \mathrm{~mJ} / \mathrm{cm}^{2}$. Membranes can be stored indefinitely when dry and at room temperature.

\section{Probe Preparation}

Oligonucleotide probes were synthesized on an Applied Biosystems 392 DNA Synthesizer with an amino-modified 

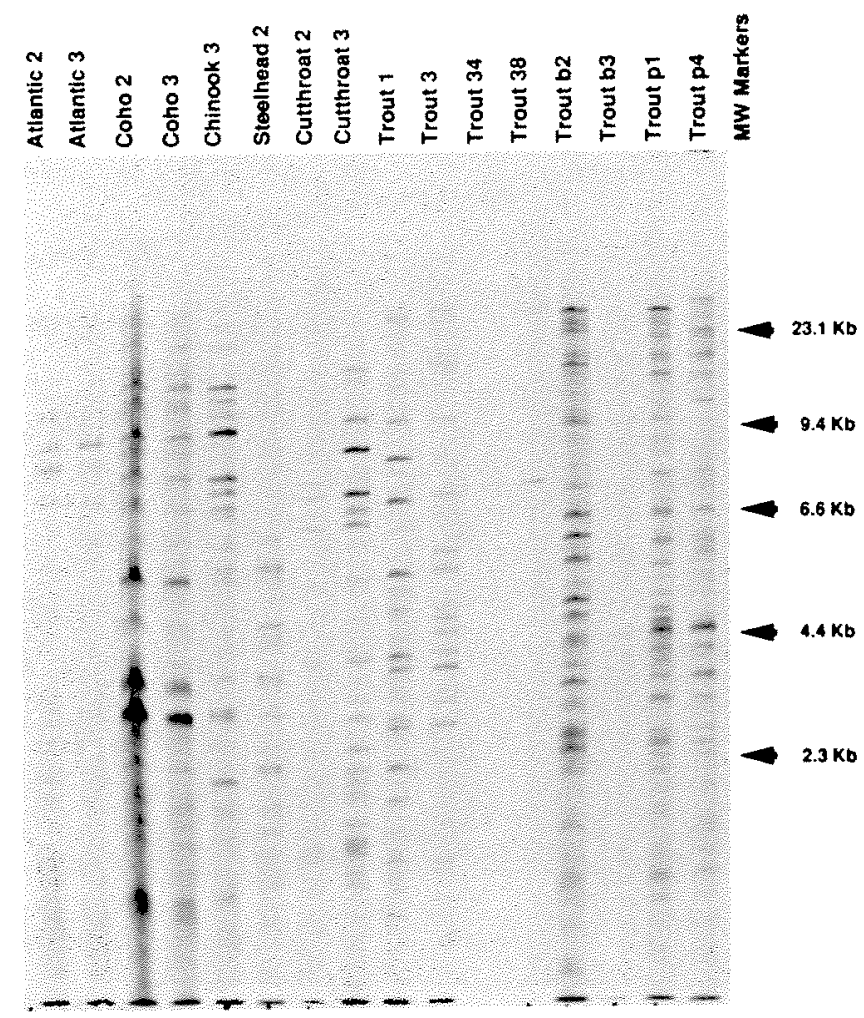

FIG. 4. DNA fingerprints of five species of salmonids. DNA from five species of salmonids was digested with HinfI and probed with a tilapia minisatellite sequence probe. Trout = rainbow trout; Chinook = chinook salmon; Atlantic = Atlantic salmon; Cutthroat $=$ Yellowstone cutthroat trout; Coho $=$ coho salmon; Steelhead $=$ steelhead.

base at the $5^{\prime}$ end (Aminolink, ABI). Alkaline phosphatase (AP) was conjugated directly to the primary amine with a Promega Lightsmith kit according to the manufacturer's instructions. Oligonucleotide probes included Jeffreys' 33.6 core sequence, $(\mathrm{CAC})_{5},(\mathrm{CA})_{12}$, a tilapia minisatellite sequence (Wright 1989; Franck and Wright 1993), an Atlantic salmon minisatellite sequence (Bentzen and Wright 1993), and a chinook salmon minisatellite sequence obtained from Table $2 b$.

\section{Hybridization and Chemiluminescent Detection}

Dried membranes were placed inside glass hybridization tubes (Robbins Scientific Model 310 Hybridization Incubator) and prehybridized for $20 \mathrm{~min}$ at the appropriate temperature in $5 \times \mathrm{SSC}, 0.5 \% \mathrm{BSA}, 1 \% \mathrm{SDS}(33.6$ core at $55^{\circ} \mathrm{C},(\mathrm{CAC})_{5}$ at $35^{\circ} \mathrm{C},(\mathrm{CA})_{12}$ at $55^{\circ} \mathrm{C}$, tilapia probe at $55^{\circ} \mathrm{C}$, Atlantic probe at $42^{\circ} \mathrm{C}$, and chinook probe at $60^{\circ} \mathrm{C}$ ). Prehybridization solution was decanted and replaced with $5 \mathrm{~mL}$ of the same solution containing DNA probe at concentration ranged from 0.5 to $1.0 \mathrm{pmol} / \mathrm{mL}$. Hybridization occured for $20 \mathrm{~min}$ and the hybridization temperature was probe specific at the temperatures listed above. Two washes were performed for 5 min using $1 \times$ SSC, $1 \%$ SDS, and two more washes were performed for 5 min with $1 \times \mathrm{SSC}$, $1 \%$ Triton X-100 at the temperature of hybridization. Membranes were then transferred to a clean plastic container and were washed twice for 5 min each with $0.3 \%$ Tween 20 in
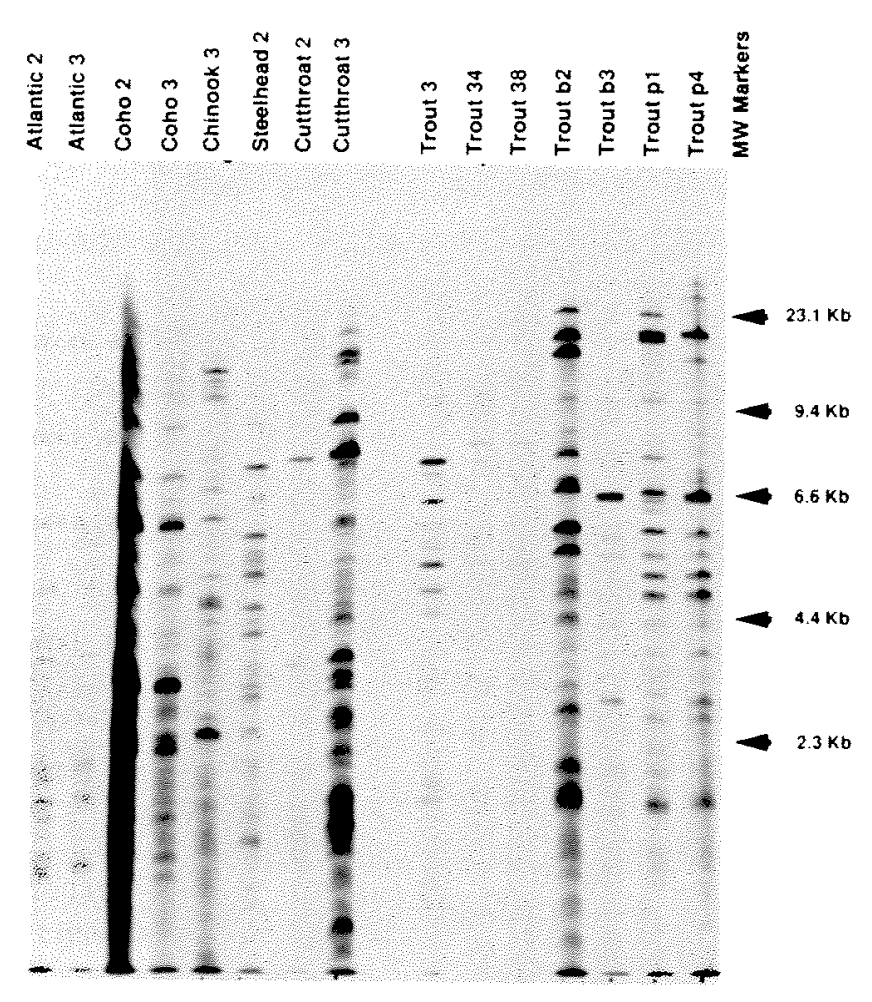

FIG. 5. DNA fingerprints of five species of salmonids. DNA from five species of salmonids was digested with HaeIII and probed with a tilapia minisatellite sequence probe. Trout $=$ rainbow trout; Chinook = chinook salmon; Atlantic = Atlantic salmon; Cutthroat $=$ Yellowstone cutthroat trout $;$ Coho $=$ coho salmon; Steelhead $=$ steelhead .

$1 \times$ PBS $\left(0.4 \mathrm{M} \mathrm{Na}_{2} \mathrm{HPO}_{4}, 0.1 \mathrm{M} \mathrm{NaH}_{2} \mathrm{PO}_{4}, 1.0 \mathrm{M} \mathrm{NaCl}\right.$, $\mathrm{pH}$ 7.4) at room temperature. Membranes were then washed once in assay buffer $\left(0.1 \mathrm{M}\right.$ diethanolamine, $\left.1 \mathrm{mM} \mathrm{MgCl}_{2}\right)$ for $5 \mathrm{~min}$ and then covered for $10 \mathrm{~min}$ with $15 \mathrm{~mL}$ of assay buffer containing $60 \mu \mathrm{g} / \mathrm{mL}$ of Lumigen PPD chemiluminescent substrate (Lumigen Inc., Detroit, MI). Damp membranes were wrapped in plastic wrap and immediately exposed to Kodak XAR-5 film for 1-3 h. After detection and scoring of bands, the membranes were stripped of the probe by washing four times for $5 \mathrm{~min}$ each with boiling $0.1 \times$ SSC, $0.1 \%$ SDS, followed by a room temperature rinse with $2 \times$ SSC. Stripped membranes were stored at $4^{\circ} \mathrm{C}$ for reprobing.

\section{Construction of Chinook Low $\mathrm{C}_{\mathrm{o}} \mathrm{t}$ Genomic Library}

Genomic chinook DNA $(\sim 440 \mu \mathrm{g})$ was sheared with a sonicator into fragments ranging in size from 200 bp to $2.5 \mathrm{~kb}$. The sheared DNA was then heat denatured by boiling and was incubated at $60^{\circ} \mathrm{C}$ for $7 \mathrm{~min}$. Double-strand DNA (dsDNA) was separated from the single-strand DNA with a hydroxylapatite column. The recovered dsDNA was then blunt-ended and cloned into pUC 18 and transformed into $E$. coli. The pUC 18 library was screened with the 33.6 core sequence as a probe. One of the clones that hybridized to the 33.6 core sequence probe was subjected to sequence analysis in both orientations by the dideoxy chain termination method (Sanger et al. 1980). 


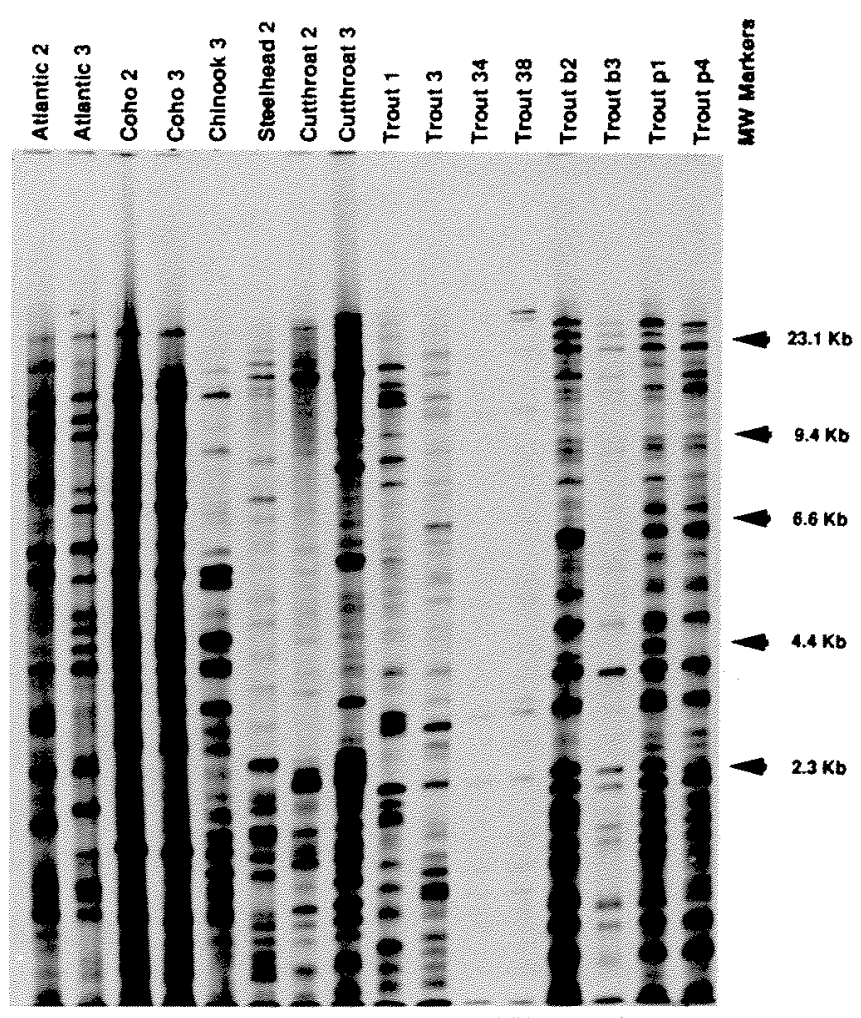

FIG. 6. DNA fingerprints of five species of salmonids. DNA from five species of salmonids was digested with $H$ inf I and probed with an Atlantic salmon minisatellite sequence probe. Trout $=$ rainbow trout Chinook $=$ chinook salmon; Atlantic $=$ Atlantic salmon; Cutthroat $=$ Yellowstone cutthroat trout; Coho $=$ coho salmon; Steelhead $=$ steelhead .

\section{Results}

Using Jeffreys' 33.6 core sequence as a probe, complex (ranging from 20 to 40 bands per lane) and highly variable fingerprints were obtained from five salmonid species. This high variability along with high levels of background are common when using a heterologous probe. However, we optimized the hybridization temperature and stringency during washing to significantly improve the overall fingerprint for generating individual specific fingerprints in all five species (Fig. 1). There were even higher backgrounds in the fingerprints when the microsatellites $(\mathrm{CAC})_{5}$ and $(\mathrm{CA})_{12}$ were used as probes in the assay (Figs. 2 and 3 ). When the tilapia and the Atlantic salmon minisatellite sequences were used as probes, clear polymorphic DNA fingerprints were obtained from all five salmonid species.

Autoradiograms with salmonid genomic DNA digested with Hinf 1 and HaellI and probed with the tilapia minisatellite probe are shown in Figs. 4 and 5. Autoradiograms with salmonid genomic DNA digested with Hinfl and HaeIII and probed with the Atlantic salmon minisatellite probe are shown in Figs. 6 and 7. In general, DNA fingerprints generated with either the tilapia or the Atlantic salmon minisatellite sequence probes showed clear and less complex profiles compared with the fingerprints generated with the Jeffreys' 33.6 core sequence or the microsatellite $(\mathrm{CAC})_{5}$ and $(\mathrm{CA})_{12}$ sequence probes.

We used this fingerprinting assay to identify the parents of unexpected albino rainbow trout in our hatchery (Fig. 8).
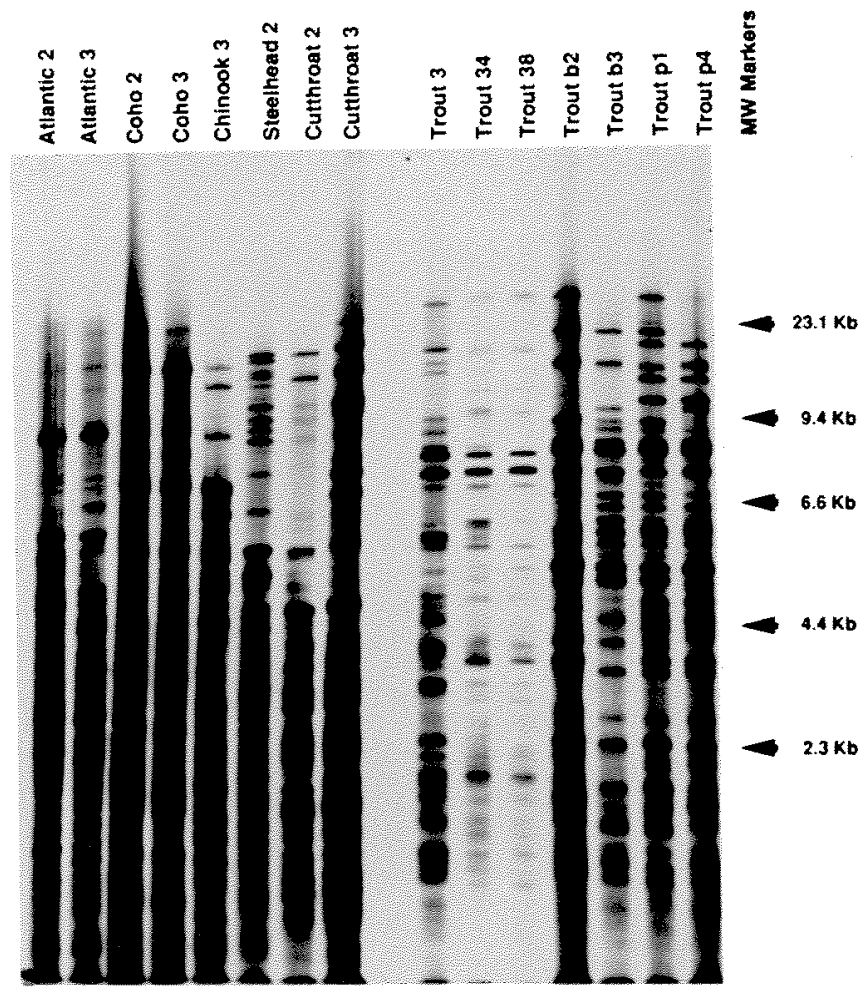

FIG. 7. DNA fingerprints of five species of salmonids. DNA from five species of salmonids was digested with HaeIII and probed with an Atlantic salmon minisatellite sequence probe. Trout $=$ rainbow trout; Chinook $=$ chinook salmon; Atlantic $=$ Atlantic salmon; Cutthroat $=$ Yellowstone cutthroat trout Coho $=$ coho salmon; Steelhead $=$ steelhead.

DNA from three of the albino offspring and the four potential parents was fingerprinted and analyzed. Because our broodstock is a more closely related group than an outbred population, we expect more than $50 \%$ band sharing between parents and offspring. We determined that fish AP-1 and AP- 4 were the parents of the three albino offspring, AB-1, $\mathrm{AB}-2$, and $\mathrm{AB}-3$.

From the pUC 18 library containing the repetitive sequences from the Chinook genomic DNA, we sequenced one of the clones that hybridized to the 33.6 core sequences. The sequences of the insert are shown in Table 1. Four types of repeats were identified within this insert and are shown in Figs. 2a-2d. One type of repeat is characterized as a dinucleotide repeat of $(C T)_{n}$. The other three repeats containing the C/GAGG motif that hybridized to the 33.6 core sequence probe are as follows: TAA TAT AAT GAC AGT AGA TGG TAG ACC AGG G; GGA GAG AGG GAG CAG G; and GAG G.

We generated a chinook minisatellite AP probe based on the sequence listed on Table $2 b$ and used it to fingerprint the five salmonid species genomic DNA cut with HinfI and HaeIII (Figs. 9 and 10). Clear DNA fingerprints were obtained with the trout, steelhead, and cutthroat DNAs. Minimum hybridization was observed with Atlantic salmon DNA. High intense hybridization (smear) without clear DNA profiles were seen with the chinook and coho salmon DNA. These data suggest that many copies of this minisatellite sequence are widely distributed within the chinook and coho salmon genomes but not in Atlantic salmon, suggesting that 
TABLE 1. Nucleotide sequence of a colony from a Chinook salmon low $\mathrm{C}_{6} \mathrm{t}$ DNA pUC library.

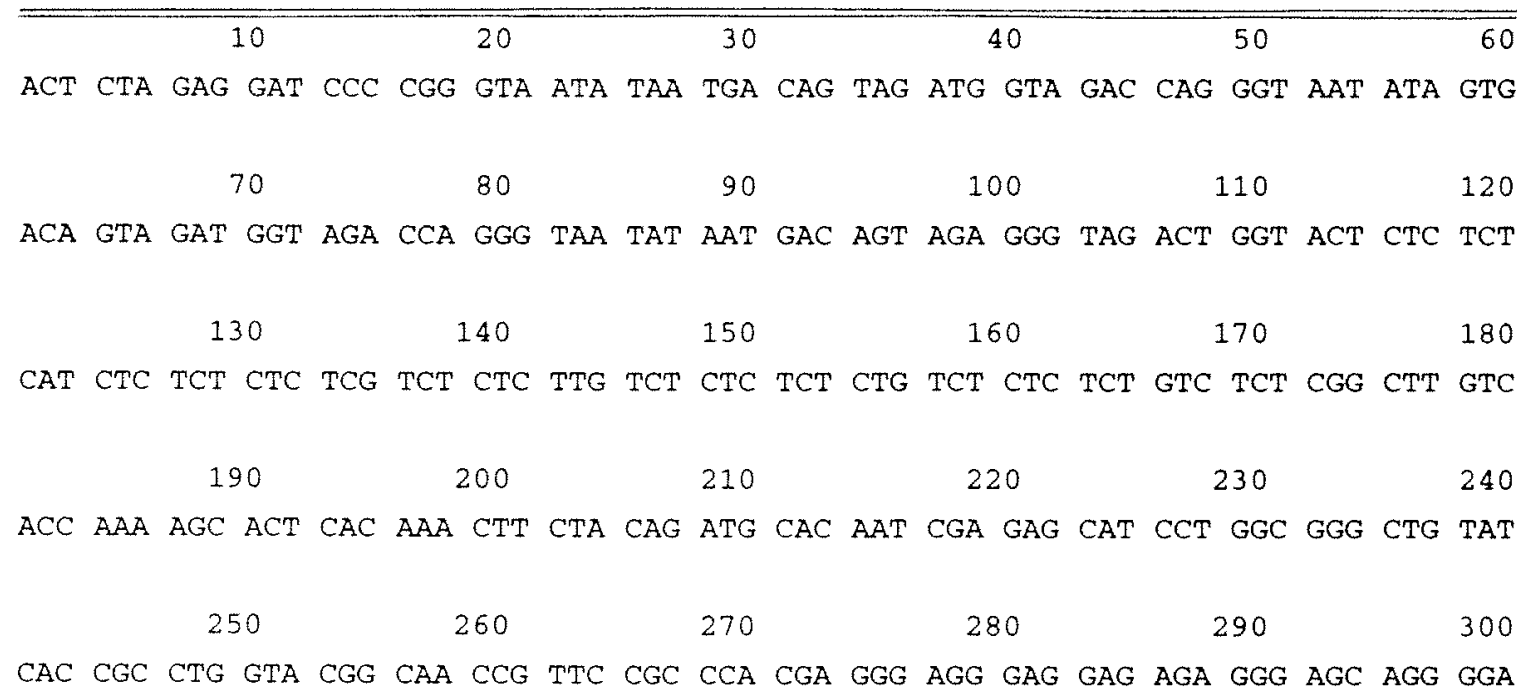

310

GAG AGG GAG GAG GGC A

the chinook sequence from Table $2 b$ is a species-specific minisatellite sequence.

\section{Discussion}

We demonstrated the use of heterologous probes for DNA fingerprinting individuals in salmonid fish. A common problem in using the 33.6 core sequences and microsatellite sequences of $(\mathrm{CAC})_{5}$ and $(\mathrm{CA})_{12}$ as probes is the high background in the fingerprints as reported by other investigators (Wright 1993). We were able to reduce general background by altering the stringency of hybridization temperature and posthybridization washes so that a clear and informative multilocus fingerprint was obtained. However, the application of minisatellite sequences from tilapia, Atlantic salmon, and chinook salmon as DNA probes gives clear, precise, low background, and less complex fingerprints that can be easily used for analysis.

Because most of the probes used in this study detect between 2 and 40 bands per DNA lane, it is possible to identify species specific markers. However, the use of these probes as definitive species and population markers must be validated with a larger sample size. Most importantly, since each probe used in DNA fingerprinting hybridizes to different regions of the genome, the application of population markers must be carefully analyzed and characterized. The ability of the DNA fingerprinting assay to identify individuals in a closely inbred population and to identify of paternal and maternal relationships proves the power of this approach in genetic identification. In fact, when a well characterized probe is used, it is feasible to use DNA fingerprinting as a genetic marker of hatchery fish, therefore providing a genetic data base for fisheries management and practices.

We demonstrated that the use of fish repetitive sequences as probes is the most practical approach in developing informative DNA fingerprints. Bentzen et al. (1994) used a homologous probe based on the tandem repeats in an Atlantic salmon minisatellite and obtained clear and highly informative multilocus DNA fingerprints for salmonid fish. Stevens et al.
(1993) reported the cloning of a multilocus B2-2 probe from a chinook salmon genomic DNA library, and they compared fingerprints using the B2-2 multilocus and single-locus Atlantic salmon 3.15 .34 probes. Using the B2-2 probe, 8 to 20 fragments were detected in any given DNA lane among five families of chinook salmon. They demonstrated that the B2-2 probe detected autosomal, unlinked, predominantly heterozygous DNA fragments that were inherited in a Mendelian fashion.

Some of the reported repetitive sequences show species and genus specificity and have been used for phylogenetic studies. Naruse et al. (1992) isolated and characterized a highly repetitive interspersed sequence, OLR1, from genomic DNA of medaka, Oryzias latipes. They found that the OLR 1 sequence is conserved in three other species, Oryzias lozonensis, Oryzias curvinotus, and Oryzias mekongnensis but not in Oryzias minutillus, Oryzias celebensis, Oryzias melastigma, Oryzias javanicus, P. formosa, and P. sphenops. Goodier and Davidson (1993) isolated a repetitive sequence from the Atlantic salmon and showed the sequence to be highly species specific. Only brown trout (Salmo trutta) DNA hybridized to the Atlantic salmon repetitive sequence and no hybridization occurred with other related species including Arctic charr (Salvelinus alpinus), Japanese white-spotted char, brook trout (Salvelinus fontinalis), rainbow trout, chum salmon, chinook salmon, pink salmon (Oncorhynchus gorbuscha), coho salmon, masu salmon (Oncorhynchus masou), and Arctic grayling (Thymallus arcticus).

Murata et al. (1993) isolated several short interspersed elements and used the polymerase chain reaction to determine the phylogenetic relationships among Pacific salmonids. Their deduced data suggest three evolutionary lines: a line of chum salmon, pink salmon, and kokanee (Oncorhynchus nerka); a line of coho salmon and chinook salmon; and a line of steelhead trout. Their data also support the change in the phylogenetic assignment of steelhead trout from Salmo to Oncorhynchus. Kido et al. (1991) used the tRNA-derived retroposons repetitive sequences to substantiate the phylogenetic relationships among salmonid species. When we 


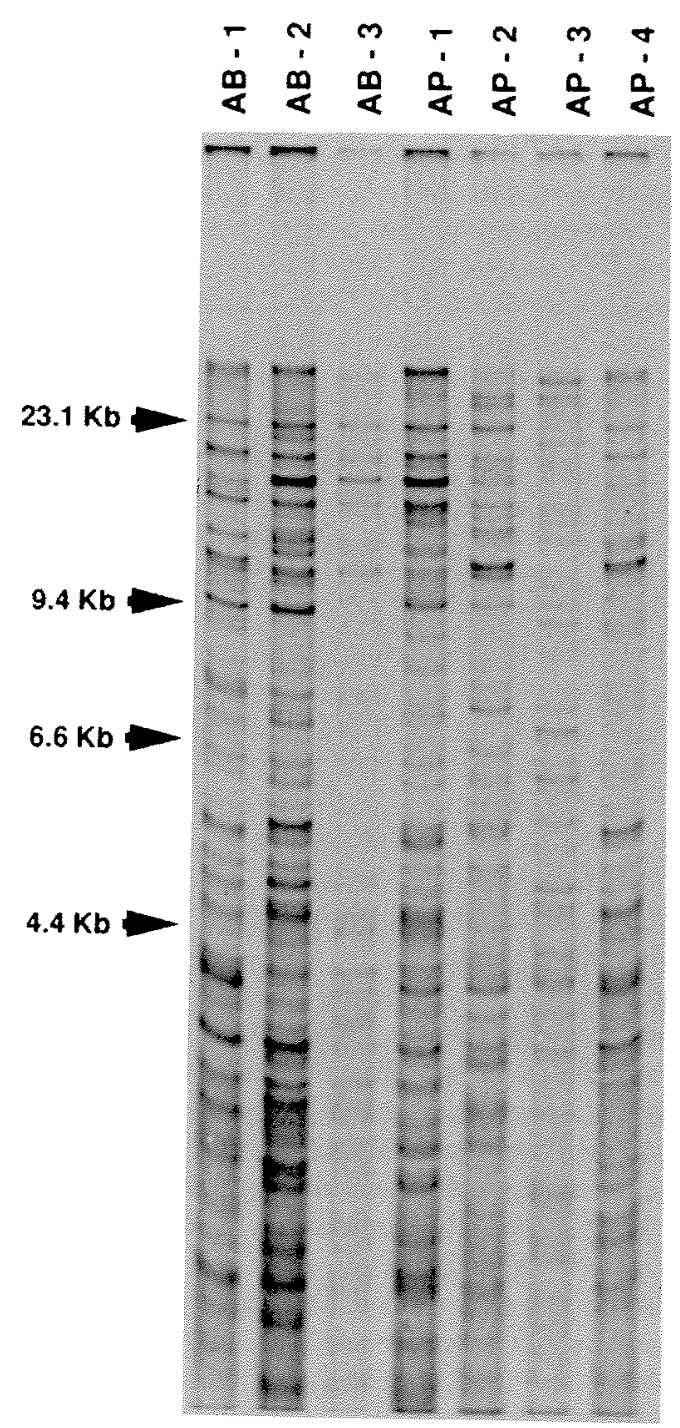

FIG. 8 DNA fingerprints from three albino rainbow trout and four suspected albino parents. DNA was digested with $A l u \mathrm{I}$ and probed with 33.6. $\mathrm{AB}=$ albino brood; $\mathrm{AP}=$ suspected albino parents.

used our chinook repetitive sequence (Table $2 b$ ) as a probe in a DNA fingerprinting assay, we demonstrated that the chinook and coho genomes contain many copies of this repeat and the trout and Atlantic salmon contain fewer copies, suggesting a close genetic relationship between coho and chinook salmon among the five species of salmon Figs. 9 and 10). These data suggest that the use of repetitive sequences is one of the best available methods for clarifying the phylogenetic order of closely related species.

Most researchers obtain the minisatellite VNTR loci by first constructing a genomic library and subsequently screening it with the 33.6 and 33.15 probes (Bentzen et al. 1991; Taggart and Ferguson 1990). Repetitive sequences are found in all eukaryotic genomes (Brutlag 1980; Singer 1982; Miklos 1985), and they are characterized by their annealing kinetics (Britten and Kohne 1968). We circumvented these time consuming and labor intensive approaches by creating a pUC library with the enriched repetitive sequences isolated from genomic DNA. Repetitive sequences were enriched from total genomic DNA by their annealing temperature characteristics which we term low- $\mathrm{C}_{0} \mathrm{t}$ DNA.

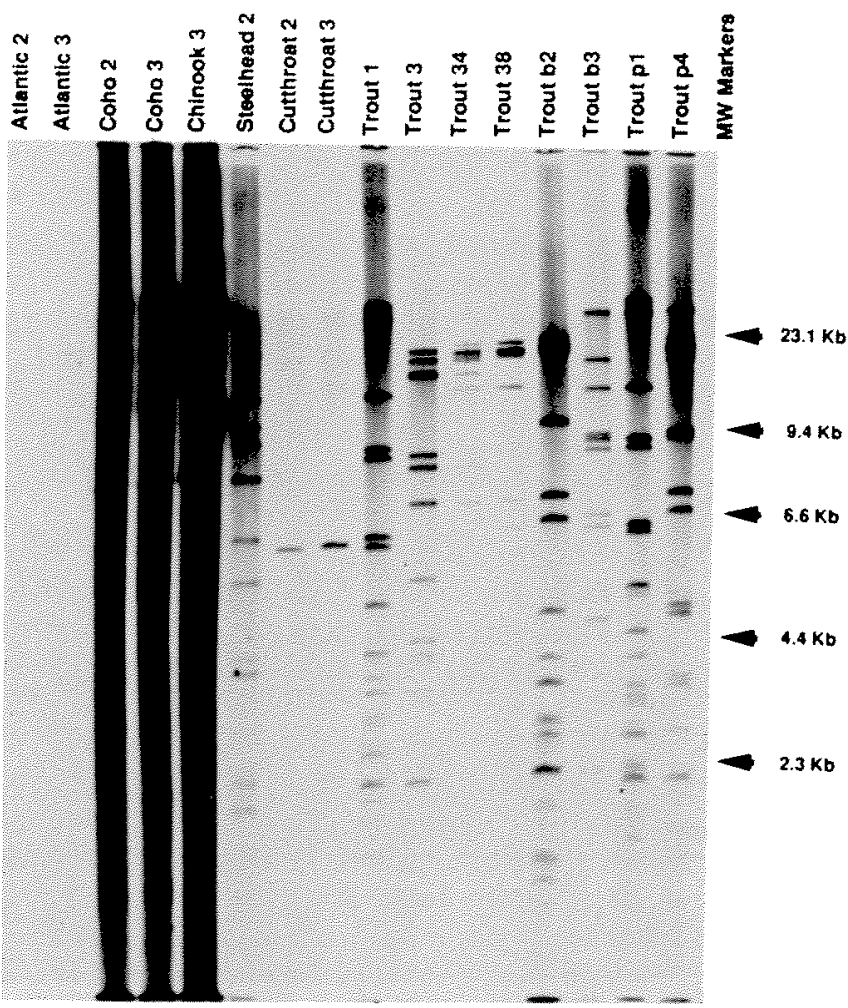

FIG. 9. DNA fingerprints of five species of salmonids. DNA from five species of salmonids were digested with Hinfl and probed with a chinook salmon minisatellite sequence probe. Trout $=$ rainbow trout; Chinook = chinook salmon; Atlantic = Atlantic salmon; Cutthroat = Yellowstone cutthroat trout; Coho = coho salmon; Steelhead $=$ steelhead.

TABLE 2. Nucleotide sequences of four different repeats from Chinook salmon. The underlined $\mathrm{G}$ in $2 \mathrm{~b}$ represented a single bp substitution.

(a)

$(\mathrm{CT})_{4} \mathrm{CAT} \quad(\mathrm{CT})_{5} \mathrm{CGT} \quad(\mathrm{CT})_{3} \mathrm{TGT} \quad(\mathrm{CT})_{5} \mathrm{GT} \quad(\mathrm{CT})_{4}$

(b)

TAA TAT AAT GAC AGT AGA TGG TAG ACC AGG G

TAA TAT AGT GAC AGT AGA TGG TAG ACC AGG $G$

TAA TAT AAT GAC AGT AGA GGG TAG AC

(c)

GGA GAG AGG GAG CAG G

GGA GAG AGG GAG GAG $G$

(d)

GAG $G$

GAG $G$

GAG $G$

We successfully used the low- $\mathrm{C}_{0}$ t DNA as a probe to distinguish different species of pathogenic fungi (Leung et al. 1992). Our strategy allows faster access to the sequence of 


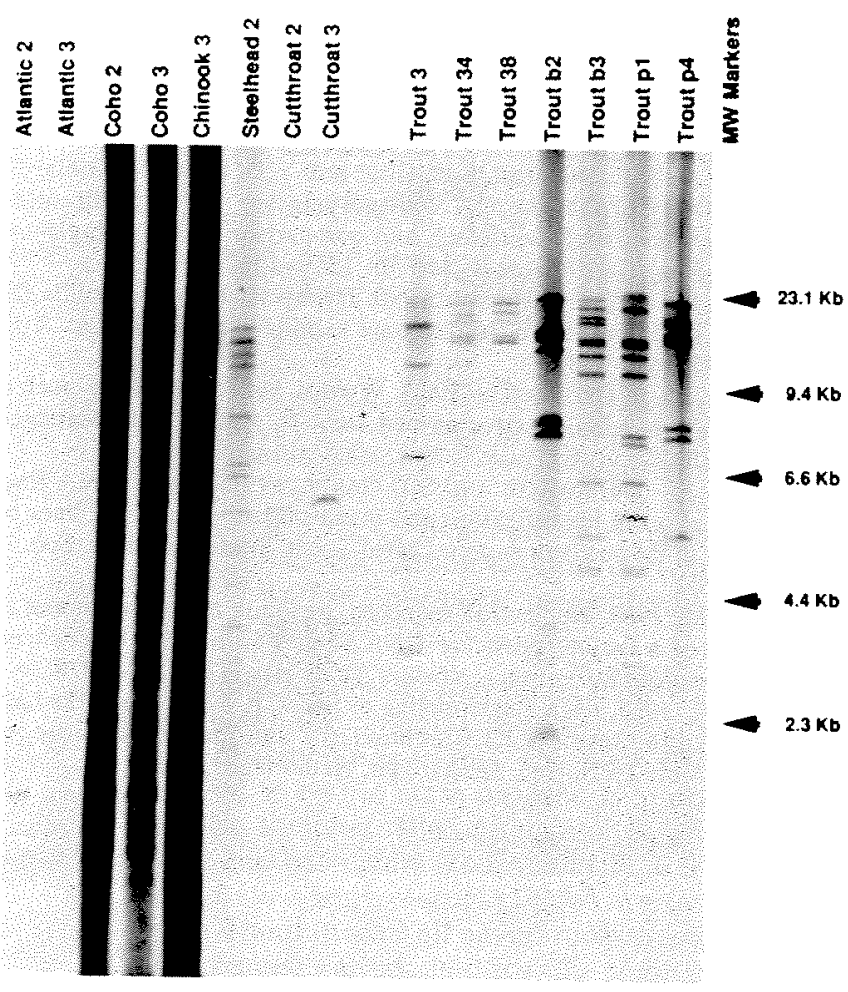

FIG. 10. DNA fingerprints of five species of salmonids. DNA from five species of salmonids was digested with HaeIII and probed with a chinook salmon minisatellite sequence probe. Trout $=$ rainbow trout $;$ Chinook $=$ chinook salmon; Atlantic $=$ Atlantic salmon; Cutthroat = Yellowstone cutthroat trout; Coho $=$ coho salmon; Steelhead $=$ steelhead.

many, but not all, of the VNTR loci. We identified four types of repeats from one insert. Three of the repeats contained the CGAGG or GGAGG motif and one contained a dinucleotide $(\mathrm{CT})_{n}$ repeat. We then generated a synthetic oligonucleotide probe based on one repeat (Table $2 b$ ) and used it as a probe in DNA fingerprinting. This repetitive sequence is widely distributed within the chinook and coho genomes, resulting in smears in the fingerprints (Figs. 9 and 10), but not in rainbow trout, which give clear and precise DNA fingerprints. This approach enabled us to quickly develop DNA probes for detecting highly variable regions of the genome in fish species. These probes will then provide us the tools to study pedigree and linkage analysis, paternity testing, breeding programs, and the analysis of genetic structure within populations.

Identification and characterization of minisatellite VNTRs in salmonids will definitely offer better probes for DNA fingerprinting. Even though the biological functions of these VNTRs remain to be determined, they will offer immediate help in quantitative genetic studies in fisheries and aquacultural sciences. Recently, Bentzen and Wright (1993) reported an evolutionarily conserved minisatellite VNTR in Atlantic salmon demonstrating the use of VNTRs for studying fish molecular evolufion. Application of DNA fingerprinting technology in fisheries is still in its infancy. Sequence information represents the data base for genetic analysis, but rapid development of new technology will make it simple to apply DNA fingerprinting to the study of aquaculture genetics and fisheries biology problems.

\section{Acknowledgments}

The authors wish to thank Steve Duguay for collecting blood samples and Gary Thorgaard for technical suggestions. The authors also wish to thank D.P. Chandler and D.W. Weaver for technical assistance. Pacific Northwest Laboratory is operated by Battelle Memorial Institute for the U.S. Department of Energy under Contract DE-AC06-76RLO 1830.

\section{References}

Aebersold, P.B., G.A. Winans, D.J. Teel, G.B. Milner, and F.M. Utter. 1987. Manual for starch gel electrophoresis: a method for the detection of genetic variation. NOAA Tech. Rep. NMFS 61.

ARNASON, U., AND B. WIDEgREN. 1984. Different rates of divergence in highly repetitive DNA of cetaceans. Heriditas 101: 171-177.

Bentzen, P., A.S. Harris, and J.M. WRIGHT. 1991. Cloning of hypervariable minisatellite and simple sequence microsatellite repeats for DNA fingerprinting of important aquacultural species of salmonids and tilapia, p. 243-262. In T. Burke, G. Dolf, A. J. Jeffreys and R. Wolff, [ed.] approaches and applications, DNA fingerprinting: Birkhauser Verlag, Basel, Switzerland.

BENTZEN, P., E.B. TAYLOR, AND J.M. WRIGHT. 1994. A novel synthetic probe for DNA fingerprint salmonid fish. J. Fish Biol. (In press).

BENTZEN, P., AND J.M. WRIGHT. 1993. Nucleotide sequence and evolutionary conservation of a minisatellite variable number tandem repeat cloned from Atlantic salmon, Salmo salar. Genome 36: 271-277.

BRITTEN, R.J., AND D.E. KOHNE. 1968. Repeated sequences in DNA. Science (Wash., DC) 161: 529-540.

BRUTLAG, D.L. 1980. Molecular arrangement and evolution of heterochromatic DNA. Annu. Rev. Genet. 14: 121-144.

CHEN, Z.-Q., C.C. LIN, AND R.B. HODGETTS. 1989. Cloning and characterization of a tandemly repeated DNA sequence in the crane family (Gruidae). Genome 32: 646-654

DATTA, U., P. DUTTA, AND R.K. MANDAL. 1988. Cloning and characterization of a highly repetitive fish nucleotide sequence. Gene $62: 331-336$.

Davis, W.C., R.A. LaRsen, and M.L. MonaGHaN. 1990. Genetic markers identified by immunogenetic methods. Am. Fish. Soc. Symp. 7:

DENOVAN, E.M., AND J.M. WRIGHT. 1990. A satellite DNA family from pollock (Pollachius virens). Gene 87: 279-283.

EPPlEN, J.T., H. AMMER, C. EPPlen, 1991. Oligonucleotide fingerprinting using simple repeat motifs: a convenient, ubiquitously applicable method to detect hypervariability for multiple purposes, p. 50-69. In T. Burke, G. Dolf, A. J. Jeffreys and R. Wolff [ed.] DNA fingerprinting: approaches and applications. Birkhauser Verlag, Basel,
Switzerland.

Fanning, T.G., H.N. Seuanez, and L. Forman. 1989. Satellite DNA sequences in the neotropical marmoset Callimico goeldii (Primates, Platyrrhini). Chromosoma 98: 396-401.

FieldS, R. D., K.R. JohnSON, AND G.H. ThORGAaRd. 1989. DNA fingerprints in rainbow trout detected by hybridization with DNA of bacteriophage M13. Trans. Am. Fish. Soc. 118: 78-81.

FRANCK, J.P.C. AND J.M. WRIGHT. 1993. Conservation of a satellite DNA sequence (SATB) in the tilapiine and haplochromine genome (Pisces: Cichlidae). Genome 36: 187-194.

GoOdiER, J.L., AND W.S. DAVIDSON. 1993. A repetitive element in the genome of Atlantic salmon, Salmo salar. Gene 131: 237-242.

Harris, A.S., S. BIEgER, R.W. DOYLE, AND J.M. WRIGHT. 1991. DNA fingerprinting of tilapia, Oreochromis niloticus, and its application to aquaculture genetics. Aquaculture 92: 157-163.

Kido, Y., M. AnNo, T. Yamaki, K. Matsumoto, S. Murata, M. Saneyoshi, AND N. OKADA. 1991. Shaping and re-shaping of salmonid genomes by amplification of tRNA-derived retroposons during evolution. Proc Natl. Acad. Sci. U.S.A. 88: $2326-2330$. KIRBY, L.T. 1992. DNA fingerprinting, an introduction. Stockton Press,
New York, NY.

Leung, F.C., D.P. Chandler, X.-Z, Shen, A.E. Jarrell, and R.J. Fellow. 1992. Use of repetitive sequences for the identification of host-specific DNA fragments in Fusarium oxysporum. In American Phytopathological Society Meeting, Portland, Oreg., abstract A28.

LloYd, M.A., M.J. FiEldS, AND G.H. ThORGAARD. 1989. BKm minisatellite sequences are not sex associated but reveal DNA fingerprint polymorphisms in rainbow trout. Genome 32: 865-868.

MikLOS, G.L. 1985. Localized highly repetitive DNA sequences in verte- 
brate and invertebrate genomes p. 241-321. In Molecular evolutionary genetics. Plenum Press, New York, NY.

MOYER, S.P., D.P. MA, T.L. ThOMAS, AND J.R. GOLD. 1988. Cloning and characterization of a highly repeated satellite DNA from the cyprinid fish Notropis lutrensis. Comp. Biochem. Physiol. B Comp. Biochem 91: 639-646.

Murata, S., N. Takasakl, M. Sartoh, and N. OKada. 1993. Determination of the phylogenetic relationships among Pacific salmonids by using short interspersed elements (SINEs) as temporal landmarks of evolution. Proc. Natl. Acad. Sci. U.S.A. 90: 6995-6999.

Naruse, K., H. Mitani, and A. Shima. 1992. A highly repetitive interspersed sequence isolated from genomic DNA of the medaka, Oryzias latipes, is conserved in three other related species within the genus Oryzias. J. Exp. Zool. 262: 81-86.

Rico, C., U. Kuhnlein, and G.J. Fitzgerald. 1991. A DNA probe that yields highly informative DNA fingerprints for the threespine stickleback. Trans. Am. Fish. Soc. 120:809-815.

ROHRER, G.A., L.J. ALEXANDER, J.W. KeELE, T.P. SMTTH, AND C.W. BEATTIE. 1994. A microsatellite linkage map of the porcine genome. Genetics 136: $231-245$.

Sanger, F., A.R. Coulson, B.G. Barrell, A.J.M. Smith, and B.A. Roe. 1980. Cloning in single-stranded bacteriophage as an aid to rapid DNA sequencing. J. Mol. Biol. 143: 161-178.

SHiElds, B.A., A.R. KAPUSCINSKI, AND K.S. GUISE. 1992. Mitochondrial DNA variation in four Minnesota populations of lake whitefish: utility as species and population markers. Trans. Am. Fish. Soc. 121: $21-25$.
SINGER, M.F. 1982. Highly repeated sequences in mammalian genomes, Int. Rev. Cytol. 76: 67-112.

SMith, P.J., A.J. Birley, A. JAmieson, AND C.A. Bishop. 1989. Mitochondrial DNA in the Atlantic cod, Gadus morhua: lack of genetic divergence between eastern and western populations. J. Fish Biol. 34: 369-377.

Stevens, T.A., R.E. Withler, S.H. Goh, AND T.D. BEACham. 1993. New multilocus probe for DNA fingerprinting in chinook salmon (Oncorhynchus tshawytscha), and comparisons with a single-locus probe. Can. J. Fish. Aquat. Sci. 50: 1559-1567.

Tagoart, J.B., AND A. Ferguson. 1990. Hypervariable minisatellite DNA single locus probes for the Atlanta salmon. Salmo salar L. J. Fish Biol. 37: 991-993.

WALDMAN, J.R., J. GRosSFIELD, AND I. WIRGIN. 1988. Review of stock discrimination techniques for striped bass. N. Am. J. Fish. Manage. 8: $410-425$.

WIRGIN, I.I., C. GRUNwald, AND S.J. GARTE. 1991. Use of DNA fingerprinting in the identification and management of a striped bass population in the southem eastern United States. Trans. Am. Fish. Soc. 120: $273-282$.

WRIGHT, J.M. 1989. Nucleotide sequence, genomic organization and evolution of a major repetitive DNA family in tilapia (Oreochromis mossambicus/hornorum). Nucleic Acids Res. 17: 5071-5079.

WRIGHT, J.M. 1993. DNA fingerprinting of fishes, p. 57-91. In J. Hochachka and P. Mommsen [ed.] Biochemistry and molecular biology of fishes. Vol. 2 Elsevier, Amsterdam, Netherlands. 